\title{
The Effect of Intervention Using a Gamification- Based Morphological Approach on the Writing Skills of Children with Poor Writing Skills
}

\author{
Hyo Hee Kim ${ }^{a}$, Youngmee Lee ${ }^{a}$, Ki-Hyung Hong ${ }^{b}$, Young Tae Kim ${ }^{a}$ \\ a'Department of Communication Disorder, Ewha Womans University, Seoul, Korea \\ ${ }^{b}$ Department of Service Design Engineering, Sungshin Women's University, Seoul, Korea
}

Correspondence: Young Tae Kim, PhD Department of Communication Disorders, Ewha Womans University, 52 Ewhayeodae-gil, Seodaemun-gu, Seoul 03760, Korea

Tel: $+82-2-3277-2410$

Fax: +82-2-3277-2122

E-mail: youngtae@ewha.ac.kr

Received: April 4, 2021

Revised: May 10, 2021

Accepted: May 11, 2021

This study was supported by the Ministry of Education of the Republic of Korea and the National Research Foundation of Korea (No. NRF2018S1A3A2075274)
Objectives: This study aimed to examine the effects of an intervention using the gamification-based morphological approach on the abilities of writing letter-sound non correspondences in children with poor writing skills. Methods: In this study, a multi-probe design was used to verify the effect of intervention. The subjects were three children with poor writing skills (grade 2-3). Their writing skills were examined through tests of treated and untreated graphemes (eojeols) in the baseline, intervention, and maintenance phases. In this study, we applied the morphological approach that helps students to write the letter-sound noncorrespondences through a game. Additionally, we provided instruction that helps them to learn the morphological knowledge and phonological rules. Each student was trained twice a week for 10-14 sessions. Results: All students were found to have high improvements in the letter-sound non correspondences eojeols. In the generalization phrase, all students showed improvements. In the maintenance phase, all students were found to have a similar effect size. Conclusion: First, gamification-based morphological approach on writing skills promote awareness of morphological knowledge in children with poor writing, and have a positive effect on letter-sound non correspondences eojeols. Additionally, training in applying morphological knowledge promotes children's writing skills that remain in the early stages of writing development. Second, gamification-based intervention can elicit interest and motivation in children with poor writing and can be repeatedly trained.

Keywords: Intervention, Gamification-base, Children, Morpheme knowledge, Phonological rules
문자를 통한 학습은 초등학교 1학년 학생들에게 반드시 적응해 야 하는 과제이며 향후에 학교 교육에 적응하는 기제로 작용한다 (Lee, 2018). 학령기에 접어들기 전에는 주로 구어적 의사소통에 익 숙했던 아동들이 문어적 문화에 적응하는 것은 쉬운 일이 아니다. 단순 쓰기 모델에 따르면, 쓰기 발달은 글씨쓰기, 철자쓰기, 작문 단 계로 발달한다. 쓰기 발달은 2-3세경부터 초기 쓰기 형태가 나타나 고, 학령기를 거쳐 점자 궁극적 목표인 작문으로 발달해간다. 여기 에는 소리를 글자로 부호화하는 과정이 필수적으로 요구되며, 이때 철자쓰기 기술이 중요하게 작용한다(Kamhi \& Catts, 2012).
철자쓰기 발달에 관한 이론은 크게 단계이론(stage theory)과 다 중언어적(multilinguistic) 이론으로 설명되고 있다. 단계이론에서 는 음운지식(phonological knowledge), 철자표기지식(orthographical knowledge), 형태지식(morphological knowledge)이 순서에 따 라 단계적인 발달을 거친다고 설명하고 있다(Goswami, 1992; Henderson, 1985). 반면, 다중언어적 이론은 음운지식, 철자표기지식, 형태지식이 통합적으로 발달하면서, 단계에 따라 강력하게 작용하 는 지식이 다르다고 설명한다(Apel, Masterson, \& Brimo, 2012; Barber, 2013; Berninger, Abbott, Nagy, \& Carlisle, 2010). 다중언어적 
이론을 바탕으로 Berninger 등(2006)이 주장한 삼중 단어 구성 이 론(triple word-form theory)에서는 철자 발달 초기에 음운지식, 형 태소 지식, 철자표기 지식이 영향을 미친다고 하였다. 세부적으로 살펴보면, 음운지식은 음소를 인식하고 조작하며 부호화 할 수 있 는 지식을 말한다(Bourassa \& Treiman, 2001). 형태지식은 어휘형 태소와 문법형태소를 표상하고 조작할 수 있도록 도우며, 이를 통 해 문어를 자소-음소 대응으로만 해석하지 않고 의미적 관련성을 고려한 철자 발달을 이루도록 한다(Nagy, Berninger, \& Abbott, 2006; Shin, Seol, Cho, Nam, \& Pae, 2015). 철자표기 지식은 글자의 조합 형태, 순서, 글자군에 대한 표상을 의미한다(Shin et al., 2015). 즉, 한글에서는 음운규칙이 적용되어 자소-음소가 불일치하는 철 자쓰기에 필요한 지식으로 설명되고 있다(Kim, 2009; Yang, 2006). 최근 한국어의 쓰기 발달도 이러한 다중언어적 이론을 기반으로 설명하고자 하는 시도가 늘어나고 있는데(Shin et al., 2015; Yang, 2014; Yang \& Lee, 2016), 일반적으로 철자 발달에 있어 음운지식은 초기에 활용된다고 보고되고 있는 반면(Adams, 1990; Frith, 1985; Henderson, 1990; Jung, 2005; Shin et al., 2015; Yang, 2014), 같은 시 기에 형태지식 활용 여부에 대해서는 그 의견이 분분하다. Yang (2009)은 유치원 후기만 되어도 경음화, 7종성 규칙과 같은 표기지 식과 형태지식이 필요한 철자를 정확하게 쓸 수 있다고 하였다. 이 와 유사하게 Shin 등(2015)은 1학년과 2학년 간에 문법형태소 오류 의 비율이 유의하게 감소하다가 3 학년에서 다시 증가하는 패턴을 보이는 것을 확인하였는데, 이를 통해 철자 발달 초기부터 음운지식 과 함께 형태지식도 지속적인 영향을 미친다고 하였다. 반면, Jung (2019)은 학령전기 아동과 초등학교 1-3학년 일반 아동을 대상으 로 철자쓰기 특성을 살펴보았는데, 형태소 수가 철자쓰기에 크게 영향을 미치지 않아 앞선 연구와는 상반된 결과를 보고하였다.

그런데 이러한 철자지식 활용에 어려움이 있는 아동들은 쓰기 시에 특정 철자를 생략하거나 대치하는 오류를 보일 수 있다(Bourassa, Treiman \& Kessler, 2006). 특히, 쓰기부진 아동은 장애가 있 는 것으로 진단되지 않은 아동 중 빈번한 철자 오류를 나타내는 아 동으로(Fletcher, Denton, \& Francis, 2005; Mattison, Hooper, \& Glassberg, 2002), 글자소 오류와 더불어 과거형 어미와 같은 관습 적인 철자 규칙을 인식하지 못하는 오류를 보인다고 보고된다(Bryant, Nunes, \& Bindman, 1999; Hebert, Kearns, Hayes, Bazis, \& Cooper, 2018). 이러한 오류는 일반 아동에 비하여 낮은 음운처리 능력, 표기지식, 형태지식, 그리고 어휘 능력에 의한 것으로 설명되 고 있다(Cunningham, Perry \& Stanovich, 2001; Holmes \& Castles, 2001; Holmes \& Ng, 1993; Kamhi \& Hinton, 2000). 이중 음운 처리 능력은 읽기와 쓰기에 공통적으로 필요한 능력으로, 읽기와
쓰기는 밀접하게 연관되어 있다(Furnes \& Samuelsson, 2010). 읽기 부진 아동은 학령기 초기에 이르기까지 음운처리과정이 정상적으 로 발휘되지 못하여 읽기에 어려움을 가지는 아동으로(Kim, Kang, \& Kim, 2019), 읽기가 부진한 아동은 철자오류도 보일 가능성이 높 다고 할 수 있다(Bruck, 1993; Cassar, Treiman, Moats, Pollo, \& Kessler, 2005; Pennington et al., 1986).

국내에서는 읽기부진 학생보다 쓰기부진 학생의 비율이 더 높다 고 보고된 바 있다(Kim \& Kim, 2015). 쓰기 학습 부진 아동과 일반 아동의 쓰기 특성을 비교한 Kim (2009)의 연구에서는 쓰기 학습 부진 아동이 일반 아동보다 모든 음운변동 규칙에서 저하된 수행 력을 보이며, 3,4 학년 이후로 철자 발달이 거의 이루어지지 않는다 고 하였다. 이와 유사하게 Park과 Chung (2008)은 쓰기부진 아동 이 자소-음소가 불일치하는 어절의 철자쓰기에서 어간과 어미의 경계를 구별하지 못하고 소리대로 표기하는 오류를 보였다고 하였 다. 또한, Lee, Choi와 Ki (2020)는 쓰기부진 아동이 일반 아동에 비 하여 형태소 오류와 글자소 오류를 더 많이 보이지만, 음운규칙 반 영 오류는 유사하게 나타났다고 보고하였다. 그러면서 일반 아동 과 쓰기부진 아동의 음운규칙 반영오류가 비슷하더라도, 일반 아 동은 음운적으로 관련 있는 음소로 대치하지만, 쓰기부진 아동은 관련 없는 음소로 대치하거나 생략하는 오류가 더 빈번하게 나타 나 질적으로 다르다고 설명하였다.

지금까지의 연구들을 종합해볼 때, 쓰기부진 아동의 쓰기 특성 을 다음과 같이 정리해볼 수 있다. 첫째, 쓰기부진 아동은 일반 아 동에 비하여 생략과 대치오류가 빈도 높게 나타난다. 둘째, 저학년 에서 고학년으로 넘어가는 시기에 철자 발달이 제대로 이루어지지 않고 고화된 패턴을 나타내며, 셋째, 자소-음소가 불일치하는 철자 에서 음운규칙 반영 오류를 빈도 높게 보인다. 이와 같은 결과를 종 합해 보면, 쓰기부진 아동은 발음와 표기가 일치하는 철자뿐만 아 니라 자소-음소가 불일치하는 철자쓰기에 지속적인 어려움이 있 다는 것을 알 수 있다. 이러한 이유로, 쓰기부진 아동의 철자쓰기 어려움을 개선하기 위해서는 자소-음소 대응원리를 이용한 중재 외에도 형태지식과 음운변동 규칙에 대한 훈련이 고려되어야 한다 (Jung, 2019; Rubin, 1988). 형태인식 중재는 크게 두 가지로 분류할 수 있는데(Hebert et al., 2018), 첫째는 철자와 발음에 중점을 두고 접사의 철자와 의미를 모두 가르치는 방법이고(Darch, Kim, Johnson, \& James, 2000; Kirk \& Gillon, 2009; Shippen, Reilly, \& Dunn, 2008; Vadasy, Sanders, \& Peyton, 2006; Vaughn et al., 2010), 둘째 는 기본 단어에 여러 종류의 접사를 결합시켜 기본 단어에서 파생되 는 합성어를 가르치는 방법이다(Archer, Gleason, \& Vachon, 2003; O'Connor, Beach, Sanchez, Bocian, \& Flynn, 2015). 예를 들어, 기 
본 단어 형태인 "happy"에 접사 "un-", "-er”을 결합시키는 과정을 강조하고 파생된 "happy-unhappy-happier"을 훈련한다. 이를 통 해 기본 단어의 변화, 단어 패턴지식, 그리고 형태소 간의 경계에 대 한 인식을 함께 훈련할 수 있으며, 이러한 중재가 효과적임을 보고하 고 있다(Apel, Diehm, \& Apel, 2013; Deacon \& Bryant, 2005; Devonshire \& Fluck, 2010; Henry, 1989; Nunes \& Bryant, 2006; Nunes, Bryant, \& Losson, 2003). 이와 같은 언어적 접근의 훈련 방법은 쓰 기부진 아동뿐만 아니라 난독 아동에게도 효과적이며(Henry, 1989; Nunes \& Bryant, 2006), 나아가 복잡하고 다양한 문장쓰기, 작문까 지도 가능하게 한다고 하였다(McCutchen, Stull, Herrera, Lotas, \& Evans, 2014; Myhill, 2008).

특히, 한국어는 풍부한 형태소로 인해 어절 단위에서 다양한 음 운규칙이 적용되고, 자소-음소 불일치 철자쓰기가 필수적으로 요 구된다(Lee, 1990). 그러나 국내에서는 문장쓰기에 대한 중재 연구 가 미미하다. Lee, Shin, Yoon과 Pae (2015)의 연구에서는 쓰기부진 초등생 2-5학년을 대상으로 형태소 및 음운변동 규칙을 활용한 중 재를 제공하였는데, 그 결과 모든 대상자의 쓰기 정확률이 향상되 었다고 보고하였다. 그리고 이와 같은 결과는 음운규칙이 빈번하게 적용되는 한국어의 특징에 기인한 것이라고 설명하였다.

그런데 읽기쓰기 훈련은 아동이 직접 읽고 쓰기를 반복하면서 학습적인 특징이 강하기 때문에, 아동의 흥미를 유발하기 어렵고 지루하다는 인식을 심어줄 수 있다. 이 같은 어려움을 보완하기 위 하여 게임을 접목시킨 중재 방법들이 소개되고 있으며, 최근에는 스마트기기를 활용한 중재가 소개되고 있다(Jang, 2018; Khowaja \& Salim, 2019; Lee \& Cho, 2010; Maria \& Jhonny, 2020; Noor, Shahbodin, \& Pee, 2012; Yi \& Lee, 2013; Zakari, Ma, \& Simmons, 2014). 게이미피케이션이란, 게임 기반의 매커니즘을 활용하는 것으로, 규 칙, 보상, 재미의 3 요소를 타분야에 통합시킴으로써 사용자의 참여 를 유도하는 것을 뜻한다. 교육적 측면에서 보면, 정적인 학습내용 을 보다 역동적이고 흥미롭게 만들어 학생의 학업 몰입도를 증진시 킬 수 있다(Park, 2017). 언어병리학에서도 게임화를 이용한 중재의 효과를 확인하려는 시도가 늘고 있으며, 긍정적인 효과를 보고하 는 선행연구가 다수 발표되었다(Khowaja \& Salim, 2019; Maria \& Jhonny, 2020; Noor et al., 2012; Yi \& Lee, 2013; Zakari et al., 2014). 또한, 읽기쓰기중재에서도 이러한 중재의 효용성이 입증되고 있으 며, 게임화를 통한 중재가 점차 다양한 대상자에게 적용될 수 있음 을 시사하고 있다(Jang, 2018; Lee \& Cho, 2010). 이에 따라 본 연구 에서는 게이미피케이션 기반의 형태론적 쓰기중재가 아동의 자소음소 불일치 어절쓰기 능력이 향상되는지 살펴보고, 쓰기중재 시 받아쓰기 정반응률과 중재의 일반화 및 유지 효과에 어떠한 영향
을 미치는지 확인하고자 하였다. 연구문제는 다음과 같다.

첫째, 게이미피케이션 기반의 형태론적 쓰기중재가 쓰기부진 아 동의 자소-음소 불일치 어절쓰기 능력을 향상시킬 것인가?

둘째, 게이미피케이션 기반의 형태론적 쓰기중재가 향상된 자 소-음소 불일치 어절쓰기 능력은 훈련하지 않은 어절에서도 일반 화될 것인가?

셋째, 게이미피케이션 기반의 형태론적 쓰기중재로 향상된 자 소-음소 불치 어절쓰기 능력은 중재가 종료된 이후에도 유지될 것 인가?

넷째, 게이미피케이션 기반의 형태론적 쓰기중재가 쓰기부진 아 동의 철자오류 유형에 따른 자소-음소 불일치 어절쓰기 능력의 변 화는 어떠한가?

\section{연구방법}

\section{연구대상}

본 연구에서는 서울 지역에 거주하는 쓰기부진 아동 3 명이 참여 하였다. 쓰기부진 아동은 저성취 모델에 근거하여 장애가 없으면서 한국어 읽기검사(KOLRA; Pae, Kim, Yoon, \& Jhang, 2015)의 받아 쓰기 검사에서 $25 \%$ ile 이하에 속한 아동이다(Lee et al., 2015). 또한 양육자 혹은 담임교사가 쓰기 학습에 어려움이 있거나 문제가 있 다고 보고하며, 한국 비언어 지능검사 제2판(K-CTONI-2; Park, 2014) 결과, 비언어성 지수에서 80 이상이고, 심각한 신체, 정서, 시 . 청각적 감각 상의 장애를 보이지 않는 아동이다. 선정 기준과 관련 한 참여 아동의 정보는 Table 1 에 제시하였다.

\section{아동 $A$ 의 특성}

아동 $\mathrm{A}$ 는 검사 당시 7세 6 개월의 초등학교 2학년에 재학 중인 남 아로, QRW (Kim et al., 2020) 검사의 문장쓰기 수행을 분석한 결

Table 1. Participants' characteristics

\begin{tabular}{lccc}
\hline Characteristic & Subject A & Subject B & Subject C \\
\hline Chronological age $(y r ; m 0)$ & $7 ; 6$ & $7 ; 7$ & $9 ; 0$ \\
Gender & Male & Male & Female \\
Nonverbal $10^{\text {a }}$ & 107 & 92 & 80 \\
Writing $^{b}$ & $5-10 \%$ ile & $<5 \%$ ile & $<5 \%$ ile \\
Writing error & & & \\
$\quad$ Letter error & $47.0 \%$ & $32.0 \%$ & $32.7 \%$ \\
$\quad$ Morpheme error & $41.1 \%$ & $48.0 \%$ & $46.5 \%$ \\
Phonological rules error & $13.7 \%$ & $20.0 \%$ & $20.6 \%$ \\
\hline
\end{tabular}

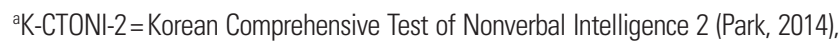
'Korean Language based Reading Assessment (Pae, et al., 2015), 'Quick Assessment of Childhood Reading \& Writing (Kim et al., 2020). 
과, 자소-음소 일치 문항 8 개 중 대치 오류를 보인 문항(내려와요 $\rightarrow$ 네려와요)을 제외하고 모두 올바르게 쓸 수 있었으며, 자소-음소 불 일치는 21 개 문항 중 16 문항에서 오류를 보였다. 자소-음소 불일치 문항 중 음운규칙 반영 오류는 $18 \%$ 이며, 나머지는 글자소 및 형태 소 오류에 속하였다. 특히, 아동 $\mathrm{A}$ 는 연음규칙을 반대로 과잉 적용 하는 오류를 2 회 보이기도 하였다(예: 하늘에서 $\rightarrow$ 한을에서). 코로 나-19로 인해 장기간 집에 머무르면서 다소 무기력한 모습이 있었으 며, 기분에 따라 불규칙한 수행력을 나타냈다.

\section{아동 $\mathrm{B}$ 의 특성}

아동 $\mathrm{B}$ 는 검사 당시 7 세 7 개월의 초등학교 2 학년에 재학 중인 남 아로, $\mathrm{QRW}$ 검사의 문장쓰기 수행을 분석한 결과, 자소-음소 일치 문항은 모두 올바르게 쓸 수 있었다. 그러나 자소-음소 불일치 21문 항 중 10 문항에서 오류를 보였는데, 이 중 음운규칙 반영 오류가 $40 \%$ 를 차지했고(닮았어요 $\rightarrow$ 달맛어요), 나머지는 글자소 및 형태 소오류였다.

\section{아동 C의 특성}

아동 $\mathrm{C}$ 는 검사 당시 9 세 0 개월의 초등학교 3 학년에 재학 중인 여 아로, $\mathrm{QRW}$ 검사의 문장쓰기 수행을 분석한 결과, 자소-음소 일치 문항 8 개 중 4 개를 정확하게 쓸 수 있었으며, 오류를 보인 문항은 불 러주는 문장을 기억하지 못하여 생략하거나, 왜곡하여 쓴 문항 3 개, 과거형 선어말 어미 '-ㅆ'을 첨가한 문항 1개가 있다. 자소-음소 불 일치 21 문항 중 15 문항에서 오류를 보였으며, 이 중 음운규칙 반영 오류가 $46 \%$ 를 차지하였다. 특히 아동 C는 음운규칙 반영 오류와 함께 글자소 오류도 빈번하게 보였으며, 과거형 선어말 어미 '-ㅆ-을 과사용한 오류가 5 회 관찰되었다(예: 비싸요 $\rightarrow$ 비쌌요).

\section{평가과제}

평가과제는 (1) 중재 단계에서 아동이 형태론적 쓰기훈련 앱을 통해 반복적으로 접하는 훈련어절과, (2) 일반화 효과를 비교하기 위해 별도의 훈련이 제공되지 않는 비훈련어절로 구성된다. 훈련어 절은 앱의 훈련단어 목록 비율을 고려하여 연음규칙과 경음규칙 을 각각 6 개씩 선정하였으며, 비음화 규칙과 격음화 규칙을 2개, 할락과 구개음화 규칙을 각각 1 개씩 선정하여 목록화 하였다. 비 훈련어절은 훈련어절과 같은 비율로 구성하였으며, 훈련어절에 포 함되지 않은 어휘형태소(예: 체언, 어간)로 선정하였고 문법형태소 (예: 어미, 조사)는 동일한 목록을 사용하였다. 평가과제는 Appen$\operatorname{dix} 1$ 에 제시된 목록과 같다.

\section{중재 프로그램}

게이미피케이션 기반의 형태론적 쓰기훈련 앱 활용

본 연구에서는 게이미피케이션 기반의 형태론적 쓰기훈련 앱으 로 한글잼잼의 쓰기단계를 활용하였다(Figure 1). 앱은 스마트기기 에 다운로드하여 실행하며, 스크린을 터치하여 조작할 수 있다. 사 용자의 반응에 따라 적절한 시 · 청각적 피드백을 제공하며, 배고픈 고양이에게 생선을 모아 주는 게임 형식으로 진행된다. 훈련어는 음운규칙이 적용되어 자소와 음소가 불일치하는 어절이며, 어휘형 태소에 다양한 문법형태소가 붙은 어절이 무작위로 제시된다. 예 를 들어, '앞은'이 나올 수도 있지만, '앞에', '앞을'과 같이 동일한 어 휘에 다른 조사가 붙은 어절이 제시될 수 있다. 해당 어절의 발음이 청각적으로 제공됨과 동시에 화면에 빈 칸이 있는 철자가 제시되

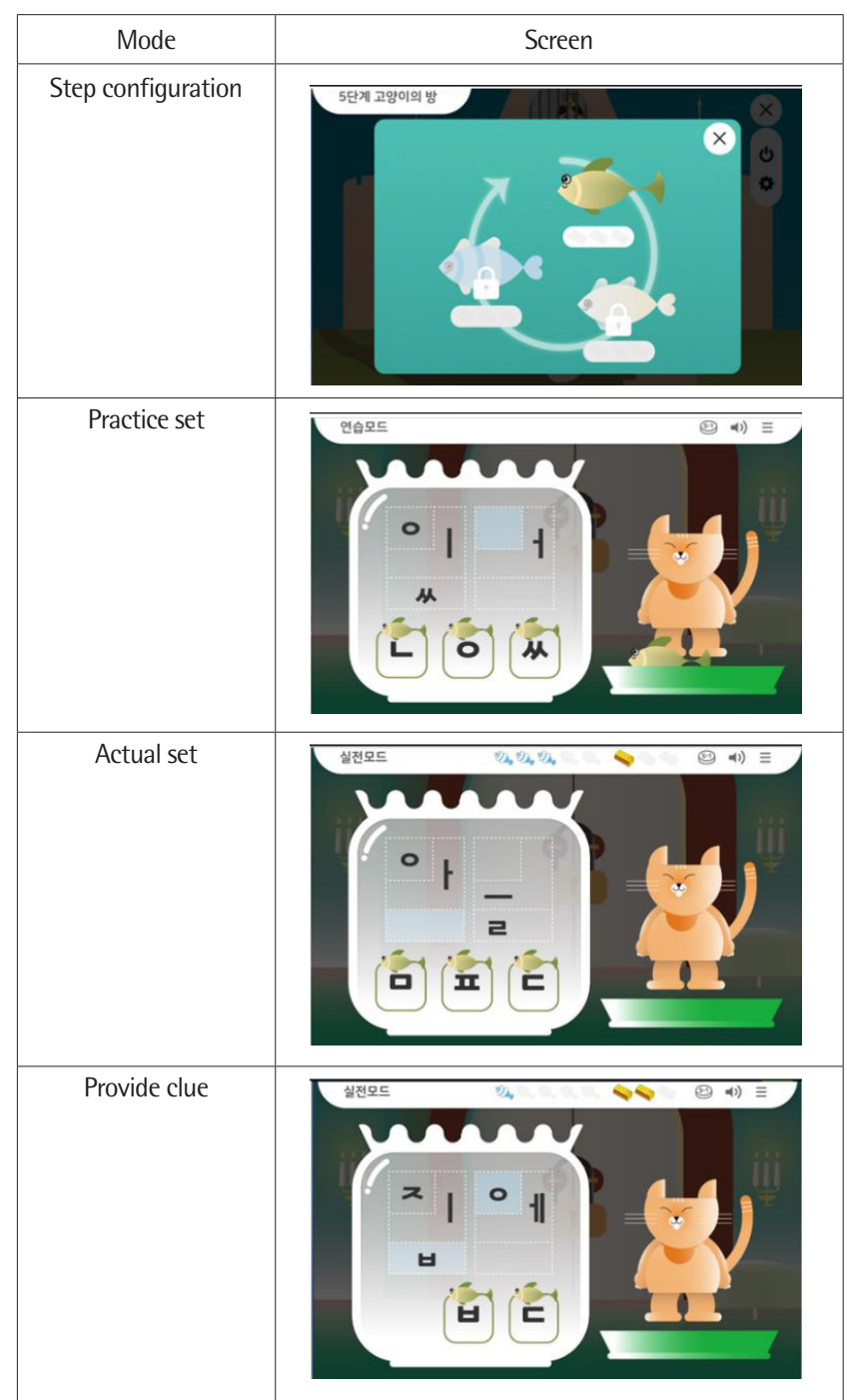

Figure 1. Hangeul Jam Jam app. source: mytalkie.co.kr. 
며, 아동은 3 개의 보기 중에서 알맞은 철자를 골라 빈 칸에 넣어야 한다. 아동이 골라야 하는 답안은 2개로, 첫 음절의 받침과 두 번째 음절의 초성 자리이다. 예를 들어, '앞은'아픈]에서 발음과 철자가 불일치하는 첫 음절의 받침 '표’자리와, 두 번째 음절의 초성 위치인 '○’자리가 빈 칸으로 제공된다. 앱의 단계는 연음화, 경음화, 기타 규칙(비음화, 격음화, ㅎㅌㅌㄹㄹㄱ, 구개음화)으로 구성되어 있으며, 단계 별로 세 개의 세트로 구성된다. 한 세트는 5 문제로, 5 문제 중 4 개 이 상을 정반응하면 세트 준거에 도달하고, 연속으로 세 개의 세트를 성공하면 단계 준거에 도달한 것으로 간주한다. 중재는 6 개의 음운 규칙(연음화, 경음화, 비음화, 격음화, 할락, 구개음화 규칙)별로 제공하였으며, 앱의 기타 규칙 단계가 4 개의 규칙을 포함하고 있으 나, 중재는 비음화, 격음화, 할락, 구개음화 규칙 순서로 진행하였 다. 앱을 통해 훈련하는 동안, 아동이 오반응하는 경우, 3 초 동안 철 자 단서가 제공되며 한 번의 기회가 더 제공된다. 이 과정을 통해 아 동은 철자를 여러 번 확인하며 훈련하고, 이후 아동이 정반응 하더 라도 앱에서는 오반응으로 채점된다. 이렇게 오반응을 보인 문항을 중심으로, 훈련 어절에 대해 한 번 더 형태지식 훈련을 제공한다. 먼 저, 표기와 발음이 일치하지 않는다는 것을 다시 확인하고, 이러한 이유가 특정한 음운규칙에 의한 것임을 설명한다. 이후, 어절을 형 태소 단위로 나누어 어휘형태소에 다른 문법형태소를 붙이는 활동 을 제공한다. 이때, 단계에 해당하는 음운규칙만 적용되도록 문법 형태소의 종류를 제한하고 그 안에서 골라 조합한다. 새롭게 만든 어절은 음운규칙을 적용하여 읽어보고, 아동이 직접 자필로 쓰면 서 스스로 여러 어절을 만들어 쓰도록 한다. 이러한 순서로 훈련을 마치면, 다시 동일한 순서로 한 번 더 중재를 제공한다. 훈련을 통해 향상된 수행력을 확인하고, 단계를 넘어가는 준거로는 첫째, 앱 내 의 단계별 준거에 도달하면서, 둘째, 받아쓰기 과제에서 규칙별 훈 련 어절의 정반응률이 $80 \%$ 이상인 경우이다.

\section{회기 구성}

본 프로그램은 아동 혼자 앱을 통해 3세트(15문제)를 풀면서 앱 에서 제공되는 단서를 통해 자소-음소 불일치 어절의 철자를 훈련 하고, 아동이 오반응한 훈련 어절을 중심으로 치료사가 형태지식 설명을 한 번 더 제공하였다.

중재 단계가 진행되는 동안 매 회기는 동일한 순서로 진행되었다. 1 단계는 형태론적 쓰기훈련 앱을 활용한 활동으로, 치료사는 아동 에게 앱을 소개하고 도달해야 할 목표를 설명해주었다. 아동은 연 습 문제를 통해 작동 방법을 익히고, 입력란을 확인한다. 실전 문제 에서는 아동 혼자 3 개의 세트를 풀도록 하며, 앱에서 제공하는 단 서를 통해 어절의 철자와 발음을 확인할 수 있다. 2 단계는 형태지식
을 활용하여 음운규칙이 적용되는 어절을 훈련하는 활동으로, 앱 에서 오반응한 훈련 어절을 중심으로 아동과 함께 목표 어절을 형 태소 단위로 분리하고, 다양한 문법형태소와 결합해 보는 활동을 실시하였다. 또한, 이 과정에서 새롭게 합성시킨 어절을 목표 음운 규칙을 적용하여 읽어보았다. 3 단계는 아동이 2 단계에서 조합해 보 았던 어절들을 직접 만들고, 자필로 써보는 활동이다. 예를 들어, 아동은 앱을 통해 어휘형태소가 같지만, 문법형태소가 다른 어절 들의(예: 춥다-춥고-춥게) 철자를 무작위로 훈련한다. 이후 연구자 는 아동과 함께 '춥다'라는 어절에서 어휘형태소인 '춥-에 다양한 어미 '-다', '-고', -게'를 붙여 다른 어절을 만드는 것을 보여주고, 아 동은 이러한 어절을 직접 조합하고 써본다.

\section{훈련 어절 구성}

본 중재 프로그램에서 사용된 훈련 어절은 어휘 친숙도, 문법형 태소의 사용 빈도와 음운규칙 유형을 고려하여 개발하였다. 어휘 목록은 저학년 미만의 아동을 대상으로 한 선행연구에서 중재에 적합하다고 언급된 어휘를 참고하여 선정하였고(Hwang, Kwon, Kim, \& Shin, 2017; Jang, Jeon, Shin, \& Kim, 2014; Kim et al., 2015), 문법형태소는 Lee와 Kim (2008)의 연구에서 초등학생의 구어에 나타난 형태소 중 $90 \%$ 이상을 차지하는 어미와 조사로 구성하였 다. 선정한 어휘형태소와 문법형태소는 형태처리 단계 유형에 속하 는 체언과 조사, 어간과 어미의 형태로 결합하여 어절을 구성하였 다(Lee, 2008). 따라서 하나의 어휘형태소에 대하여 1-3개의 파생된 어절이 목록에 포함된다. 음운규칙 유형은 학령기 아동이 습득해 야할 대표적 음운규칙인 연음화, 경음화, 격음화, 비음화 규칙(Jung, 2019)과 쓰기중재 연구를 참고하여 할락 규칙과 구개음화 규칙 을 포함하여 총 6개의 규칙으로 구성하고(Lee et al., 2015), 한국어 음운규칙에 대한 통계적 분석 결과를 참고하여 연음규칙, 경음규 칙이 적용되는 어절의 비율을 더 높게 구성하였다(Lee \& Chung, 2002). 훈련 어절 구성에 사용된 음운규칙 별 문법형태소는 Table 2 에 제시된 목록과 같다.

Table 2. Grammatical morpheme usage list by phonological rules

\begin{tabular}{lcc}
\hline \multirow{2}{*}{ Phonological rules } & \multicolumn{2}{c}{ Grammatical morpheme list } \\
\cline { 2 - 3 } & Postposition & Ending \\
\hline Lenition & -eun, -yi, -eh & -uh/ah, -eun, -eul \\
Fortification & - do & -go, -gae, -da \\
Nasalization & -man & -neun \\
Aspiration &. & -go, -gae, -da \\
Guttural sound elision &. & -uh/ah, -eun, -eul \\
Palatalization & $-\mathrm{yi}$ & $\cdot$ \\
\hline
\end{tabular}




\section{실험설계}

본 연구는 단일 대상 연구 설계(single-subject research design) 중 하나인 연구 대상자 간 중다간헐기초선설계(multiple probe design across subjects)로 설계되었다. 이 설계는 동일한 목표를 가진 세 명 이상의 아동을 중재 후 목표 행동이 적절한 수준에 도달할 수 있는지, 목표 행동이 향상된 이후에도 유지되는지를 검증하기 위해 아동 간 기초선 자료를 간헐적으로 측정하는 방법이다. 중재 단계 전까지 기초선 자료를 간헐적으로 수집하여 큰 변화가 없다는 것을 확인하며, 신뢰로운 실험통제를 입증하기 위하여 연속 3 회기 이상의 기초선 자료를 수집한다(lee, Park, \& Kim, 2000).

\section{장소 및 기간}

장소는 아동의 집에서 진행하였으며, 아동에게 친숙하고 조용한 장소인 방에서 책상에 나란히 앉아 진행하였다. 기간은 2020년 4월 부터 8 월까지였다. 중재는 주 2 회씩 1 회기 당 40 분씩 진행하였다.

\section{실험절차}

\section{중재 단계}

중재 단계는 10-14회기 동안 음운규칙 단계에 따라 진행되었으 며, 앱의 준거에 도달하여도 평가과제에서 목표 음운규칙 문항의 $80 \%$ 이상 정반응하지 않으면 다음 단계로 넘어가지 않는다. 한 회 기는 총 40 분으로 구성되며, 회기 시작과 함께 5 분간 평가과제를 실시한다. 이후 중재에서는 형태론적 쓰기훈련 앱을 통해 음운규 칙이 적용되는 어절쓰기를 훈련하고, 앱에서 오반응을 보인 문항 을 중심으로 형태지식 훈련을 실시한다. 이후 훈련 어절을 자필로 쓰는 활동까지 마쳐야 하며, 이러한 중재 순서가 매 회기 2회 반복 진행되었다.

\section{일반화 단계}

중재 전, 중재 중과 중재 후에 자소-음소 불일치 어절 받아쓰기 평가를 통해 중재 효과가 일반화될 수 있는지 알아보았다. 일반화 어절 목록은 훈련에 사용되지 않은 9 개의 어절로, 단어 선정 기준 은 훈련 평가 목록을 작성할 때와 동일하였다.

\section{유지 단계}

유지 단계는 중재 종결 후 일정한 시간이 지난 후에도 중재 효과 가 지속되는지 확인하는 단계로, 중재 종결 시점부터 2주간의 공백 기를 가진 후, 기초선과 동일한 평가과제를 연속 3 회기 평가하여 쓰 기 능력이 유지되는지 평가하였다.

\section{자료의 측정 및 분석}

자료의 측정

평가는 매 회기 중재 전 기초선과 동일한 조건으로 진행되었으 며, 훈련 어절 및 일반화 어절 받아쓰기를 통해 대상 아동의 쓰기 능력 향상 정도를 평가하였다. 자료의 측정은 아동이 바르게 적으 면 '1점, 잘못 적거나 모른다고 할 경우에는 '0점'으로 평가하고, 오 반응한 문항에 대해 선행연구를 참고하여 글자소 오류, 형태소 오 류, 음운규칙 오류로 분류하고 출현율을 분석하였다(Kim et al., 2020; Kim, 2009). 만약 두 개의 오류가 중복되어 나타나는 경우, 두 오류 모두 분석하였다. 예를 들어, '있어'를 ‘이써'로 표기한 경우, 형태소 오류와 음운규칙 오류를 중복으로 세었다. 그러나 예시와 같이 음운변동 오류의 경우, 글자소 오류를 중복하여 분석하지 않 았다. 종속변인의 조작적 정의는 Appendix 2에 제시된 목록과 같다.

1) 글자소 오류: 생략, 대치, 첨가오류로 분류하였다. 생략오류는 목표 어절 중 글자소를 생략한 경우, 대치오류는 글자소를 대 치한 경우, 첨가오류는 글자소를 첨가한 경우이다.

2) 형태소 오류: 어휘형태소, 어미, 조사오류로 분류하였다. 어휘 형태소 오류는 발음에 영향을 받아 어휘형태소가 변형되는 형 태로 어절을 표기하는 경우이며, 어미오류는 어간과 어미의 경계를 구분하지 못하여 발음에 영향을 받아 어미가 변형되 는 형태로 표기하는 경우, 조사오류는 체언과 조사의 경계를 구분하지 못하여 조사가 변형되는 형태로 표기하는 경우이다.

3) 음운규칙 오류: 연음화, 경음화, 격음화, 할락, 비음화, 구개 음화 규칙의 6 개의 음운규칙에 대하여 목표 어절의 전체를 소 리대로 표기하는 경우이다.

\section{중재의 효과 크기 분석}

본 연구에서는 중재의 효과 크기를 검증하기 위하여 중재 효과 크기(Improvement Rate Difference, IRD) 분석 방법을 사용하였 다. IRD는 중재 IR과 기초선 IR 사이의 차이를 계산하여 구한다. 중 재 IR은 기초선 단계와 중첩되지 않는 자료점의 수를 중재 단계의 총 자료점 수로 나누어 계산하며, 기초선 IR은 중재 단계와 중첩되 지 않는 자료점의 수를 기초선 단계의 총 자료점 수로 나누어 계산 한다(Parker, Vannest, \& Brown, 2009).

\section{평가자 간 신뢰도}

본 연구의 평가과제의 점수에 대한 신뢰도를 검증하기 위해 평가 자 간 신뢰도 분석을 실시하였다. 연구자와 2 급 언어재활사 1 인이 평가자 간 신뢰도 분석에 참여하였다. 평가자는 무작위로 선택된 기초선 1 회기, 중재 2 회기, 유지 1 회기의 평가과제 자료를 분석하였 
Hyo Hee Kim, et al. • Treatment Using the Gamification-Based Approach for Poor Writer

으며, 평가자 간 신뢰도는 두 평가자 간의 정오반응 일치도로 측정 하였다. 그 결과, 대상 아동별로 기초선 단계에서 $100 \%$, 중재 단계 에서는 94.4-100\%, 유지단계에서는 $100 \%$ 일치하였다.

Table 3. Content validity of target word

\begin{tabular}{llccc}
\hline & $\begin{array}{c}\text { Assessment } \\
\text { contents }\end{array}$ & Subject A & Subject B & Subject C \\
\hline Relevance & Intervention & 4.98 & 4.87 & 4.90 \\
& Generalization & 4.85 & 5 & 4.92 \\
\hline
\end{tabular}

Table 4. Mean and effect size of letter-sound non correspondences writing test score

\begin{tabular}{|c|c|c|c|c|c|}
\hline & \multirow{2}{*}{$\frac{\text { Baseline }}{\text { Mean (range) }}$} & \multicolumn{2}{|c|}{ Intervention } & \multicolumn{2}{|c|}{ Maintenance } \\
\hline & & Mean (range) & IRD & Mean (range) & IRD \\
\hline Subject A & 40.2 (38-44) & 66.3 (44-88) & $.60^{*}$ & 90.7 (88-94) & $1.0^{* *}$ \\
\hline Subject B & $49.0(38-55)$ & 79.4 (61-94) & $1.0^{* *}$ & $92.5(88-94)$ & $1.0^{* *}$ \\
\hline Subject C & 35.7 (22-44) & 74.4 (50-100) & $1.0^{* *}$ & 88.8 (88.8) & $1.0^{* *}$ \\
\hline
\end{tabular}

Values are presented as mean(range).

$\mathrm{IRD}=$ improvement rate difference; Chance level $(\mathrm{IRD}=.50)$.

${ }^{*}$ medium effect size $(.50<\mathrm{IRD}<.70)$, ${ }^{* *}$ strong effect size (IRD $\left.\geq .70\right)$.

Baseline Intervention Generalization Maintenance

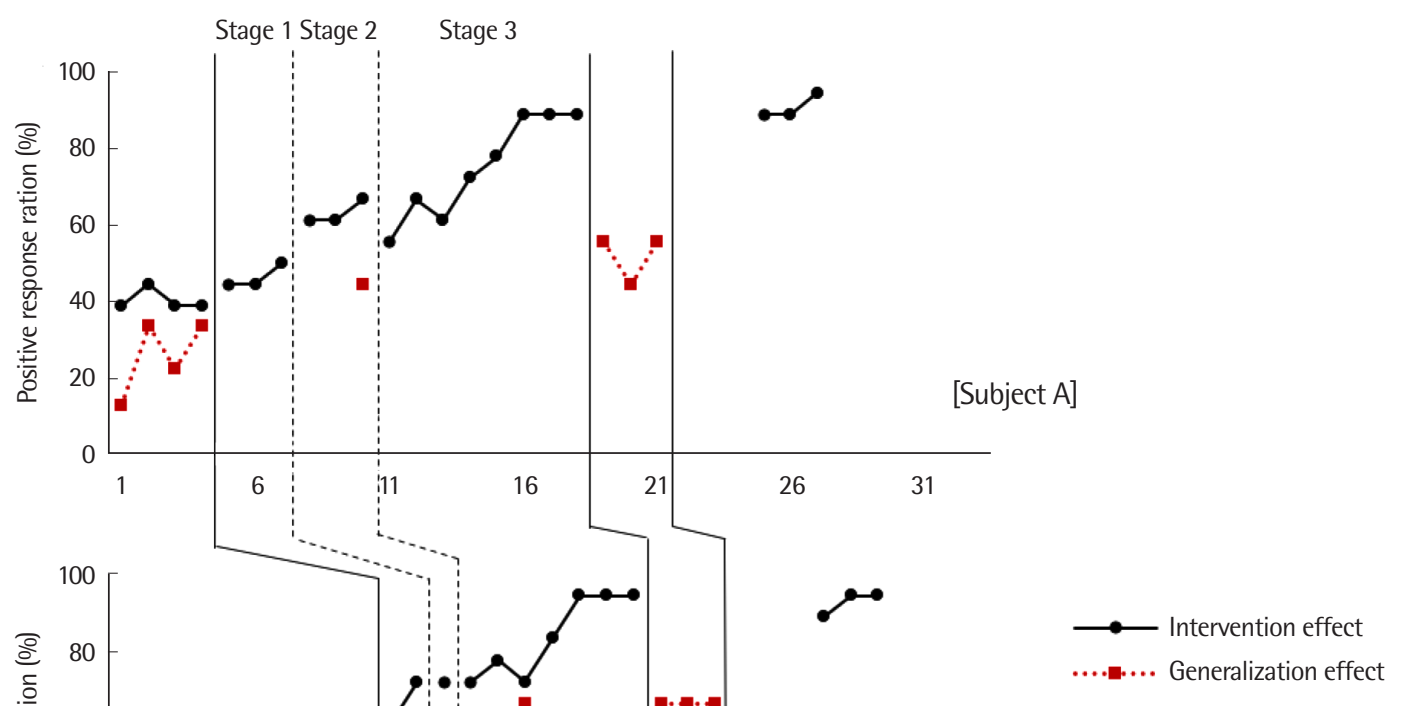

[Subject B]

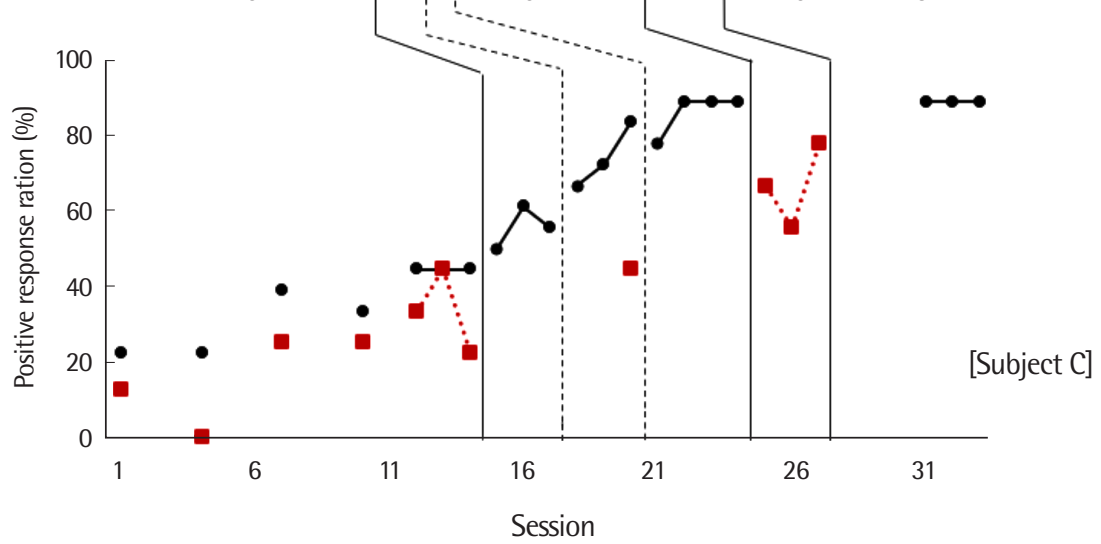

Figure 2. Mean scores of letter-sound non correspondences writing tests. 


\section{중재 충실도}

본 연구의 중재 충실도를 알아보기 위해 2 급 언어재활사 1 인이 무작위로 선정한 중재 단계의 회기 자료를 보고 중재 충실도를 평 가하였다. 대상자별로 기초선, 중재, 유지 단계에서 각 1 회기씩을 선 정하여 각 아동별로 총 3 회기를 측정하였다. 평가 내용은 연구자가 일관된 방식으로 훈련을 진행하였는지, 실험 절차가 적절한지 등이 었다. 모든 평가 방법은 설문지를 통해 이루어졌다. 평가 결과, 대상 아동 $\mathrm{A}$ 부터 대상 아동 $\mathrm{C}$ 까지의 중재 충실도는 모두 $100 \%$ 로 산출 되었다.

\section{내용타당도}

본 연구의 내용타당도를 측정하기 위해 중재 시작 전 1 급 언어재 활사 자격증을 소지한 3 명에게 온라인 설문지를 제공하여 훈련어 목록이 본 중재 목표에 적합한지 적절성 여부를 평가하도록 하였 다. 결과는 Table 3 과 같다. 설문지는 각각의 어절에 대하여 Likert 5점 척도를 사용하여 '매우 적절하지 않음(1)-매우 적절함(5점)' 중 에서 평가하였다.

\section{연구결과}

\section{게이미피케이션 기반의 형태론적 쓰기중재의 훈련 어절쓰기에 대한 훈련 및 유지 효과}

본 쓰기중재의 훈련 효과는 (1) 훈련 어절 쓰기 전체 정반응률의 변화, (2) 음운규칙별 정반응률의 변화, 그리고 (3) 오류 출현율의 변 화 측면에서 살펴볼 수 있다. 첫째, 전체 정반응률의 변화를 살펴보 면, 대상 아동들은 중재 단계에서 훈련한 자소-음소 불일치 어절쓰 기 정반응률이 향상되었다(Table 4, Figure 2). 정반응률은 대상 아 동 $\mathrm{A}$ 의 경우 기초선 단계에서 $40.2 \%$, 중재 단계에서 $66.3 \%$, 유지 단 계에서 $90.7 \%$ 의 수행을 나타냈다. 대상 아동 B는 기초선 단계에서
$49.0 \%$, 중재 단계에서 $79.4 \%$, 유지 단계에서 $92.5 \%$ 의 수행을 나타 냈다. 대상 아동 C는 기초선 단계에서 $35.7 \%$, 중재 단계에서 $74.4 \%$, 유지 단계에서 $88.8 \%$ 의 수행을 나타냈다. 중재의 영향을 받았는지 알아보기 위해 IRD로 효과크기를 구하였다. 그 결과, 대상 아동 A 의 IRD는 60 으로 중간 정도의 효과크기를 보였고, 아동 $\mathrm{B}$ 의 IRD 는 1.0 으로 매우 큰 효과크기, 아동 C의 IRD는 1.0 으로 매우 큰 효 과크기를 나타냈다. 유지 단계에서는 대상 아동 A와 B, C 모두 IRD 1.0 로으 나타나 매우 큰 효과크기를 보였다.

둘째, 음운규칙별 정반응률의 변화를 살펴보면, 모든 대상 아동 이 중재 전보다 후에서 모든 음운규칙의 평균 정반응률이 향상되 었다(Table 5, Figure 3). 특히, 할락 규칙과 구개음화 규칙은 중재 전 평균 $0 \%$ 로 저조한 수행력을 보였으나, 중재 후 향상된 정반응률 을 보였으며 중재 종결시점에서 $100 \%$ 의 정반응률을 나타냈다. 대 상 아동 A가 가장 많은 향상을 보인 규칙은 비음화, ‘ㅎ' 탈락, 비음 화 규칙이며, 반면에 연음화 규칙에서는 다소 미미한 향상을 보인 것으로 나타났다. 대상 아동 $\mathrm{B}$ 는 격음화 규칙과 구개음화 규칙에서 가장 큰 진전을 보였으며, 비음화 규칙에서는 다소 미미한 향상을 보인 것으로 나타났다. 대상 아동 $\mathrm{C}$ 는 격음화 규칙, 구개음화 규칙 에서 가장 큰 진전을 보였으며, ‘ㅎ' 탈락 규칙에서는 다소 미미한 향상을 보인 것으로 나타났다.

셋째, 오류 출현율의 변화를 살펴보면, 대상 아동들은 중재 단계 에서 모든 철자 오류 유형의 오류 출현율이 감소하였다(Figure 4). 또한, 오류 유형별 출현율의 크기를 살펴보면, 형태소 오류가 가장 빈도 높게 나타났고, 다음으로 음운규칙 반영 오류, 글자소 오류 순 으로 나타났다. 대상 아동 $\mathrm{A}$ 의 경우 글자소 오류가 기초선 단계에 서 $15 \%$, 중재 단계에서 $8 \%$ 로 감소하였고, 형태소 오류는 기초선 단 계에서 $34 \%$, 중재 단계에서 $19 \%$ 로 감소하였다. 음운규칙 오류는 기초선 단계에서 $19 \%$, 중재 단계에서 $13 \%$ 를 보이며 감소하였다. 대 상 아동 B의 경우, 글자소 오류가 기초선 단계에서 $14 \%$, 중재 단계

Table 5. Mean of letter-sound non correspondences writing test score according to the phonological rules (\%)

\begin{tabular}{|c|c|c|c|c|c|c|}
\hline & \multicolumn{6}{|c|}{ Phonological rules } \\
\hline & Lenition & Fortification & Nasalization & Aspiration & Guttural sound elision & Palatalization \\
\hline \multicolumn{7}{|l|}{ Pre } \\
\hline Subject A & $62.5(50-66.6)$ & $50(50-50)$ & $12.5(0-50)$ & $25(0-50)$ & $0(0)$ & $0(0)$ \\
\hline Subject B & 47.2 (33.3-66.6) & $50(66.6-83.3)$ & 50 (50-50) & $33.3(0-50)$ & $0(0)$ & $0(0)$ \\
\hline Subject C & $42.9(16-66.6)$ & $42.9(33.3-50)$ & $57.1(50-100)$ & $7.1(0-50)$ & $0(0)$ & $0(0)$ \\
\hline \multicolumn{7}{|l|}{ Post } \\
\hline Subject A & 77.7 (66.6-100) & $70.8(50-100)$ & $50(0-100)$ & $50(0-100)$ & $50(0-100)$ & $37.5(0-100)$ \\
\hline Subject B & $91.6(83.3-100)$ & 83.3 (66.6-100) & $68.7(50-100)$ & $93.7(50-100)$ & $37.5(0-100)$ & $62.5(0-100)$ \\
\hline Subject C & $83.3(66.6-100)$ & $72.2(50-100)$ & $100(0-100)$ & $75(0-100)$ & $25(0-100)$ & $50(0-100)$ \\
\hline
\end{tabular}

Values are presented as mean (range). 


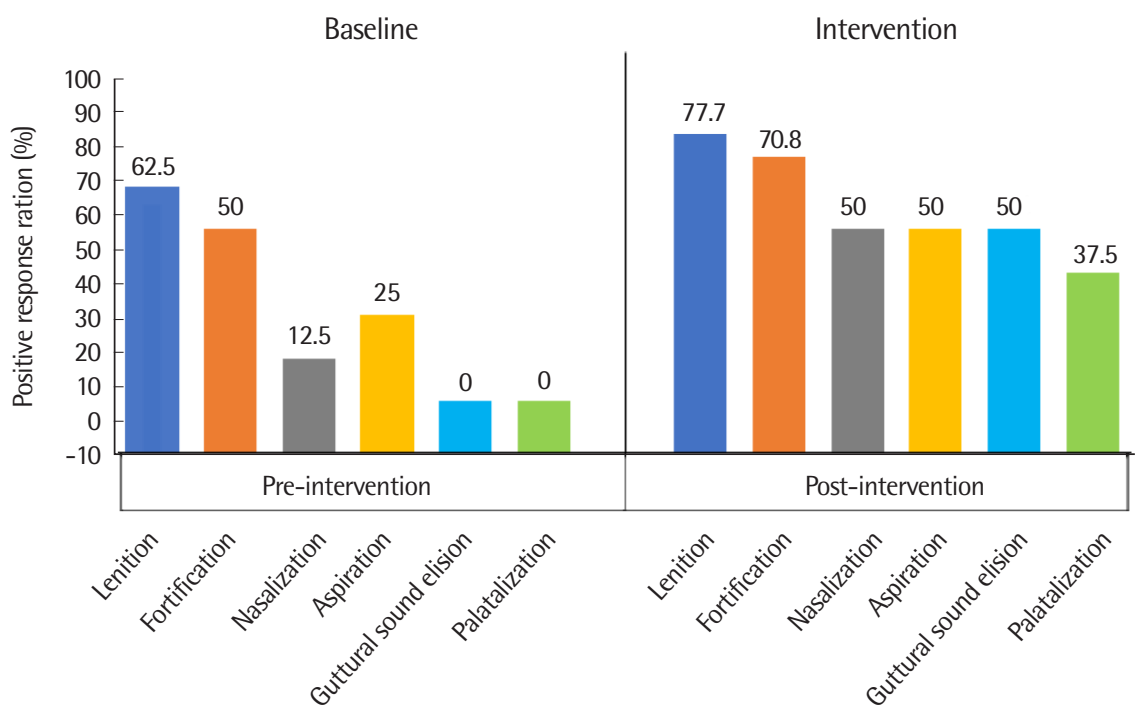

[Subject A]

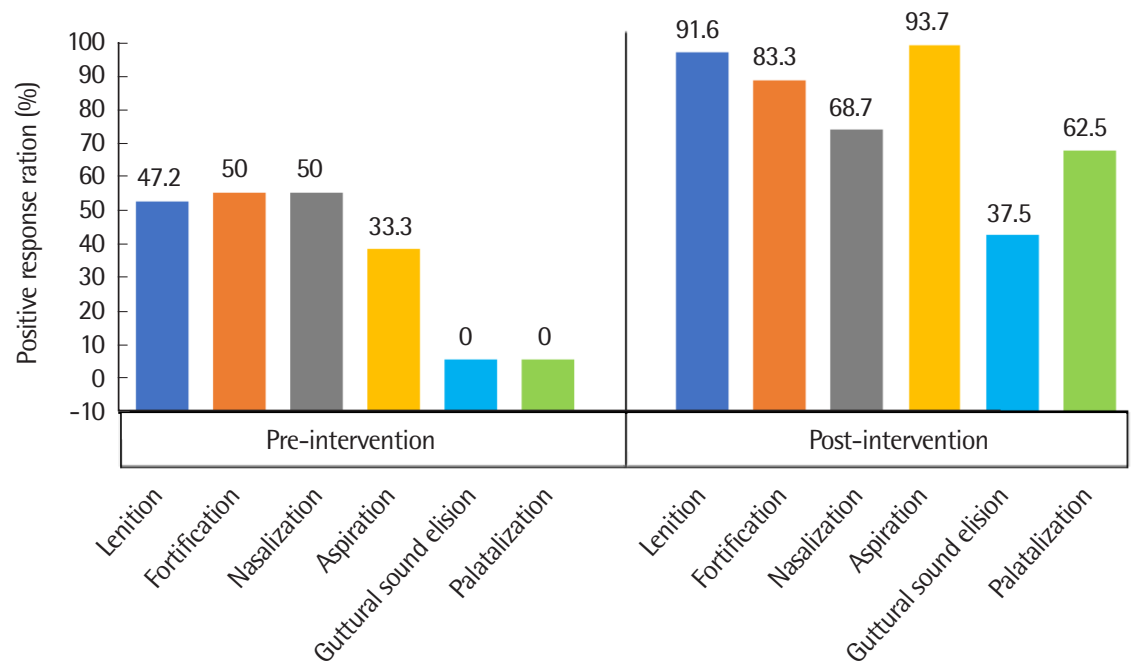

[Subject B]

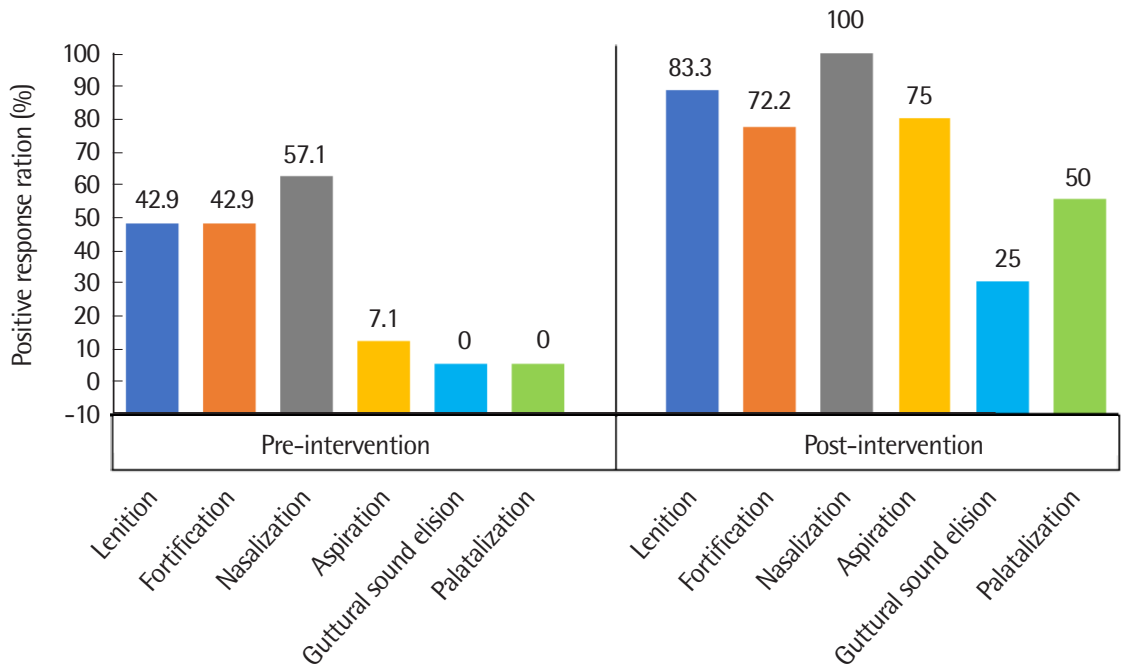

[Subject C]

Figure 3. Mean scores of letter-sound non correspondences tests according to the phonological rules. 

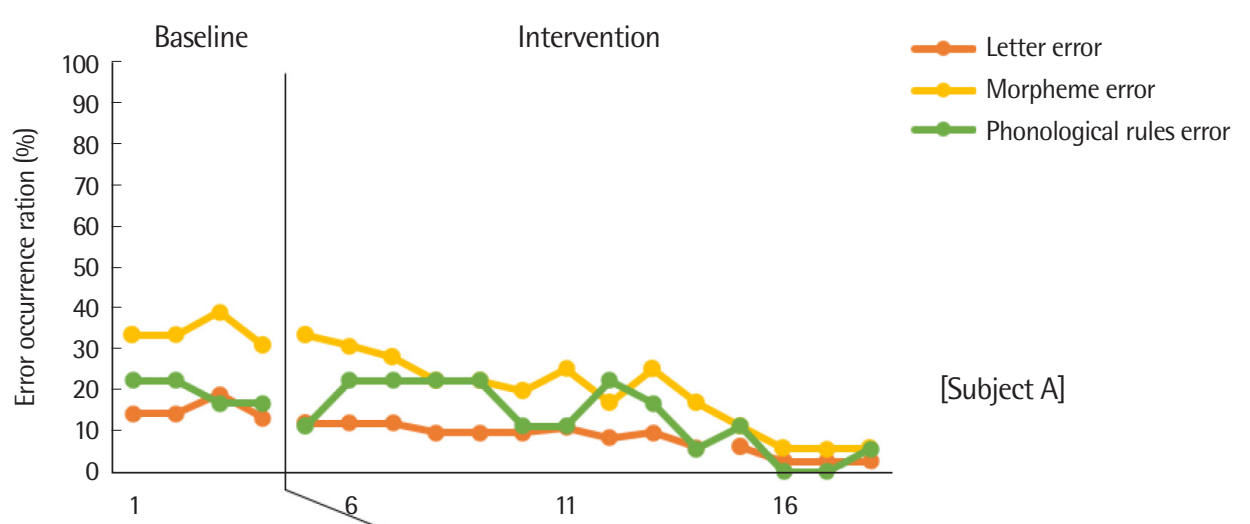

[Subject A]

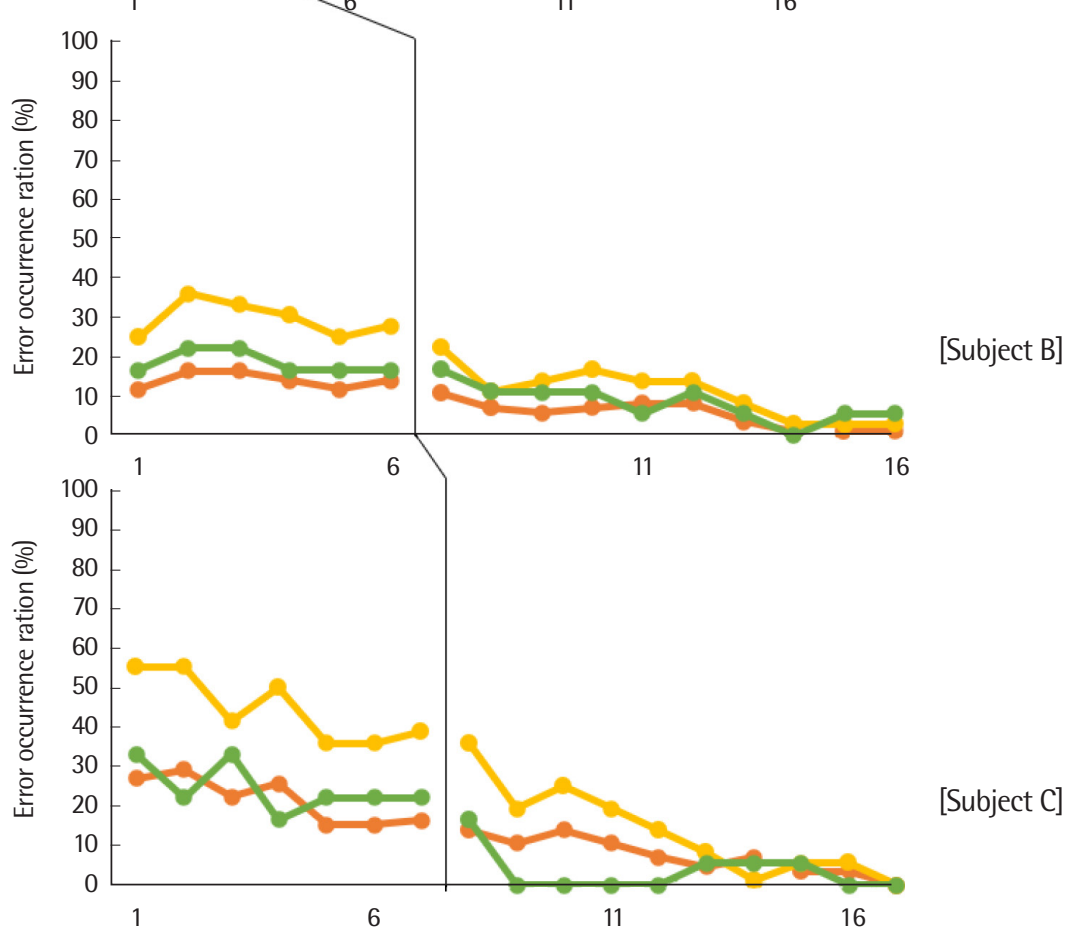

Figure 4. Occurrence rate according to the error type.

에서 $5 \%$ 로 감소하였고, 형태소 오류는 기초선 단계에서 $30 \%$, 중재 단계에서 $11 \%$ 로 감소하였다. 음운규칙 오류는 기초선 단계에서 $19 \%$, 중재 단계에서 $8 \%$ 로 감소하였다. 대상 아동 C는 글자소 오류 가 기초선 단계에서 $22 \%$ 였으나, 중재 단계에서 $8 \%$ 로 감소하였고, 형태소 오류는 기초선 단계에서 $45 \%$ 였으나, 중재 단계에서 $13 \%$ 로 감소하였다. 또한 음운규칙 오류는 기초선 단계에서 $25 \%$ 였으나, 중 재 단계에서 $3 \%$ 로 감소하였다. 모든 대상 아동의 중재 단계 종결 시 점의 철자 오류 출현율은 $10 \%$ 미만으로 나타났다.

\section{게이미피케이션 기반의 형태론적 쓰기중재의 비훈련 어절쓰기로의 일반화 효과}

일반화 평가는 중재 전 기초선 단계에서 4-7회기, 중재 단계에서
1회기, 그리고 중재가 모두 마친 직후에 연속 3회기 평가하였다. 일 반화 평가 목록은 훈련 평가 목록에 포함되지 않은 어절들로 구성 하였다. 아동 $\mathrm{A}$ 는 기초선 단계에서 연속 4 회기 동안 일반화 평가를 실시하였고, 평균 정반응률은 $25.3 \%$ (12-33\%)이다. 중재 단계에서 는 $44.4 \%$ 의 정반응률을 보여 기초선에 비해 향상된 수행력을 보였 다. 중재 직후 실시한 일반화 단계에서는 평균 $51.8 \%$ (44-55\%)의 정 반응률을 보였다. 아동 $\mathrm{A}$ 의 일반화 효과크기(IRD)는 1.0 으로 매우 큰 효과크기가 있는 것으로 나타났다. 아동 $\mathrm{B}$ 는 기초선 단계에서 6 회기 동안 일반화 평가를 실시하였고, 평균 정반응률은 43.0\% (37$50)$ 이다. 중재 단계에서는 $66.6 \%$ 의 정반응률을 보여 기초선에 비해 향상된 수행력을 보였다. 중재 직후 실시한 일반화 단계에서는 평 균 $66.6 \%$ 의 정반응률을 보였다. 아동 $\mathrm{B}$ 의 일반화 효과크기(IRD) 
는 1.0 으로 매우 큰 효과크기가 있는 것으로 나타났다. 아동 C는 기 초선 단계에서 7회기 동안 일반화 평가를 실시하였고, 평균 정반응 률은 $23.2 \%(0-44 \%)$ 이다. 중재 단계에서는 $44.4 \%$ 의 정반응률을 보 여 기초선에 비해 향상된 수행력을 보였다. 중재 직후 실시한 일반 화 단계에서는 평균 $66.6 \%$ 의 정반응률을 보였다. 대상 아동 C의 일 반화 효과크기(IRD)는 1.0 으로 매우 큰 효과크기가 있는 것으로 나타났다(Figure 2).

\section{논의 및 결론}

본 연구에서는 게이미피케이션 기반의 형태론적 쓰기중재를 쓰 기부진 아동에게 제공하고, 자소-음소 불일치 어절쓰기 능력 향상 에 효과적으로 작용하는지 알아보고자 하였다. 그 결과, 본 훈련 방 법이 대상 아동의 쓰기 정확도 향상에 효과적임을 확인할 수 있었 다. 이러한 긍정적인 효과에 기여한 요소들을 다음과 같이 논의하 고자한다.

첫째, 게이미피케이션 기반의 형태론적 쓰기중재는 대상 아동들 의 자소-음소 불일치 어절쓰기 능력을 향상시키는 것으로 나타났 다. 쓰기 오류를 유형별로 분류하여 기초선, 중재 단계의 오류 출현 율을 살펴본 결과, 모든 대상 아동의 오류 출현율이 감소하면서 정 반응률이 향상되는 추세를 보였다. 대상 아동 세 명의 철자쓰기 오 류를 살펴본 결과, 중재 시작 시점에서는 음운규칙 오류가 평균 $18 \%$, 형태소 오류가 평균 $32 \%$, 글자소 오류가 평균 $14 \%$ 로 나타났으나, 중재 종결 시점에서는 음운규칙 오류가 평균 $4 \%$, 형태소 오류가 평 균 $3 \%$, 글자소 오류가 평균 $1 \%$ 로 감소한 것을 확인할 수 있었다. 이 러한 결과는 형태지식을 활용한 쓰기중재가 쓰기부진 아동에게 효과적이었다는 선행연구들과 일치하는 결과로 볼 수 있다(Darch et al., 2000; Lee et al., 2015, Kirk \& Gillon, 2009; Shippen et al., 2008; Vadasy et al., 2006; Vaughn et al., 2010). 즉, 한글에서도 음운규칙 이 적용된 철자를 훈련함에 있어 형태지식을 활용하는 것이 효과 적일 수 있음을 시사하며, 특히 이러한 중재가 저학년 학생의 쓰기 능력에도 긍정적인 영향을 준다는 것을 의미한다. 이는 저학년 시 기에 형태지식과 표기지식이 철자쓰기에 큰 영향을 미치지 않는다 는 선행연구와는 다소 상반된 결과로(Jung, 2019), 쓰기부진 아동 의 초기 철자 발달에서 형태지식 및 표기지식의 활용여부와 이를 활용한 중재 효과에 대한 다양한 연구가 필요할 것으로 보인다.

둘째, 읽기쓰기 훈련에 있어 게임화를 활용한 중재가 효과적이 라는 선행연구와 같이(Jang, 2018, Lee \& Cho, 2010), 본 연구에서 게이미피케이션 기반의 훈련을 제공한 것이 아동의 동기와 흥미 형 성에 긍정적인 영향을 준 것으로 보인다( $\mathrm{Han}, \mathrm{Kim}, \mathrm{Kim}, \& \mathrm{Yu}$,
2014). 본 연구에서는 앱에서 제공되는 '고양이 게임'을 활용하여 쓰기훈련을 제공하였는데, 이 안에서 제공되는 시각적, 청각적 보 상과 피드백이 대상 아동의 흥미를 유발하여 참여를 높인 것으로 볼수 있다.

셋째, 본 연구에서는 아동들의 어절쓰기가 음운규칙별로 중재 전후에 어떻게 변화하는지를 확인하였다. 공통적으로 세 명의 아 동 모두 어절쓰기의 능력이 향상되었는데, 아동에 따라 상이하지 만 공통적으로 비음화 규칙과, 격음화 규칙, 할락 규칙에서 중재 종결 시점까지 오류를 나타내는 것을 확인하였다. 쓰기부진 아동 은 특히 겹받침, 구개음화, 비음화 규칙에서 높은 오류율을 보인다 고 하였는데(Shin \& Joe, 2001), 본 연구에서도 비음화 규칙에서 지 속적으로 어려움을 보이는 것으로 보아, 쓰기부진 아동은 음운 동 화로 인해 음가가 변하는 철자쓰기에 더욱 어려움이 있는 것으로 보인다. 또한 격음화 규칙의 문항에서 두 명의 아동이 지속적으로 오류를 보였는데, 이는 '싸타'와 같이 발음대로 표기하는 오류가 아 니라, 받침을 표기하되, 'ㄷ으로 대치하는 오류였다. 즉, 두 아동은 쓰기에 형태지식과 음운변동 규칙을 적용하려는 시도를 보였으나, 어휘형태소의 ‘ㅎ'받침을 인식하지 못하여 나타난 오류라고 볼 수 있으며, 이는 아동별 낱말 친숙도에 영향을 받은 것으로 볼 수 있다 (Joshi \& Aaron, 2002).

넷째, 본 연구에서는 아동들의 쓰기 오류를 오류 유형별로 살펴 보고, 아동별 쓰기 특성에 대해 살펴보았다. 대상 아동의 오류 유형 별 출현율을 살펴보면, 형태소 오류를 가장 많이 보였고, 그 다음으 로 음운규칙 오류, 글자소 오류 순으로 나타났다. 선행연구에서는 쓰기부진 아동의 형태소 및 글자소 오류가 일반 아동에 비해 유의 하게 높게 나타났다고 보고하였는데(Lee et al., 2020), 본 연구도 이 와 유사한 결과를 나타냈다. 이는 일반 아동은 형태소 전략과 철자 표기 전략을 동시에 사용하지만 쓰기부진 아동은 자소-음소를 대 응시키는 음운적 전략에 주로 의존하기 때문으로 생각해볼 수 있 다(Weiner, 1994). 다시 말해, 쓰기부진 아동의 낮은 음운변동 인식 (Kim, 2009)과 저하된 형태인식 능력이 자소-음소 불일치 어절쓰 기에 영향을 미치면서 형태소 간의 경계가 사라지고 소리나는 데로 쓰는 오류가 빈도 높게 나타났다고 볼 수 있다. 또한 동일한 훈련 어 절을 쓸 때 매 회기 표기가 달라지는 특징이 관찰되었는데, 예를 들 어 아동 A의 경우, "같아'를 "갚다", "갔타", "갓다”와 같이 매 회기 다른 철자로 표기하는 오류를 보였으며, 아동 C 역시 '좋고'를 “총 오", “좋코”, “좋오”와 같이 음운규칙에 영향을 받음과 동시에 다른 글자소로 대치하는 오류를 보였다. 이는 쓰기부진 아동이 지속적 으로 음운조작 능력이 약한 것으로 볼 수 있으며(Kamhl \& Hinton, 2000), 이 때문에 음운변동 반영 오류에서 일반 아동과 질적으 
로 다른 양상을 보인다는 선행연구의 결과와 유사하다(Lee, 2019). 본 연구에서는 다음과 같은 제한점이 있으므로, 향후 연구에서 는 이를 고려한 연구가 필요할 것으로 생각된다. 첫째, 본 연구에서 는 초등학교 2-3학년의 저학년 쓰기부진 아동을 대상으로 형태지 식과 음운규칙에 대한 훈련을 제공하였다. 아동에 따라 차이가 있 었으나 형태지식과 표기지식 훈련 시, 이해에 비하여 활용이 빠르 게 이루어지지는 않았다. 이는 초기 철자 발달에 가장 활발하게 사 용되는 전략이 음운 전략인데 비해, 본 연구에서는 형태지식과 표 기지식 중심의 훈련만 제공했기 때문이라고 생각할 수 있다. 따라 서 고학년이 될수록 표기지식과 형태지식의 중요도가 더욱 증가한 다는 점을 고려하여(Green et al., 2003; Henderson, 1990; Sangster \& Deacon, 2011, Treiman, Cassar, \& Zukowski, 1994), 음운지식 훈 련과 함께 형태 및 표기지식을 촉진하는 중재의 효과를 확인하는 것도 의의가 있을 것이다. 둘째, 본 연구에서 사용한 형태론적 쓰기 훈련 앱은 아동이 직접 쓸 수 있는 기회가 제공되지 않았기 때문에, 앱으로만 중재를 제공하는 것은 자필쓰기로의 일반화가 어려울 수 있다는 제한점이 있다. 자필쓰기는 일종의 주관식 평가로, 선택이 나 재인 기능 보다는 재생과 기억의 기능을 요구하기 때문에, 일반 적으로 객관식 평가보다 어렵다고 할 수 있다(Sung, 1988). 따라서 아동이 직접 쓸 수 있는 기회가 제공되는 훈련 도구를 활용한다면, 보다 명확하게 중재 효과를 확인할 수 있을 것이다. 셋째, 본 연구에 서는 평가과제를 6 개의 음운변동 규칙(연음화, 경음화, 비음화, 격 음화, 할락, 구개음화)으로 구분하여 목록화 하였고, 음운규칙별 훈련 어절의 비율에 따라 비훈련 어절의 목록을 구성하였다. 이 중 격음화 규칙에 대한 어절이 일반화 평가 목록에서 제외되어 격음화 규칙에 대한 일반화 효과를 확인할 수 없었다. Jung (2019)의 연구 에서 대표적인 음운변동 규칙으로 보고된 연음화, 경음화, 비음화 격음화 규칙을 고려하여, 일반화 평가 목록에 이러한 음운변동 규 칙을 모두 포함한다면 더욱 명확하게 일반화 효과를 확인할 수 있 을 것이다.

\section{REFERENCES}

Adams, M. (1990). Beginning to read: thinking and learning about print. Cambridge, MA: MIT Press.

Apel, K., Diehm, E., \& Apel, L. (2013). Using multiple measures of morphological awareness to assess its relation to reading. Topics in Language Disorders, 33(1), 42-56.

Apel, K., Masterson, J. J., \& Brimo, D. (2012). Spelling assessment and intervention: a multiple linguistic approach to improving literacy outcomes. In A.
G. Kamhi \& H. W. (Eds.), Language and reading disabilities (pp. 226-243). Boston, MA: Pearson.

Archer, A. L., Gleason, M. M., \& Vachon, V. L. (2003). Decoding and fluency: foundation skills for struggling older readers. Learning Disability Quarter$l y, 26(2), 89-101$.

Barber, A. (2013). Multilinguistic components of spelling: an overview. Perspectives on Language Learning and Education, 20(4), 124-128.

Berninger, V. W., Abbott, R. D., Nagy, W., \& Carlisle, J. (2010). Growth in phonological, orthographic, and morphological awareness in grade 1 to 6 . Journal of Psycholinguistic Research, 39(2), 141-163.

Berninger, V. W., Abbott, R. D., Jones, J., Wolf, B. J., Gould, L., AndersonYoungstrom, M., ... \& Apel, K. (2006). Early development of language by hand: composing, reading, listening, and speaking connections; three letter-writing modes; and fast mapping in spelling. Developmental Neuropsychology, 29(1), 61-92.

Bryant, P., Nunes, T, \& Bindman, M. (1999). Morphemes and spelling. In T. Nunes (Ed.). Learning to read: an integrated view from research and practice (pp. 15-42). Dordrecht: Kluwer.

Bruck, M. (1993). Component spelling skills of college students with childhood diagnoses of dyslexia. Learning Disability Quarterly, 16(3), 171-184.

Bourassa, D. C., \& Treiman, R. (2001). Spelling development and disability: the importance of linguistic factors. Language, Speech, and Hearing Services in Schools, 32(3), 172-181.

Bourassa, D. C., Treiman, R., \& Kessler, B. (2006). Use of morphology in spelling by children with dyslexia and typically developing children. Memory and Cognition, 34(3), 703-714.

Cassar, M., Treiman, R., Moats, L., Pollo, T. C., \& Kessler, B. (2005). How do the spellings of children with dyslexia compare with those of non-dyslexic children?. Reading and Writing, 18(1), 27-49.

Cunningham, A. E., Perry, K. E., \& Stanovich, K. E. (2001). Converging evidence for the concept of orthographic processing. Reading and Writing, 14(5), 549-568.

Darch, C., Kim, S., Johnson, S., \& James, H. (2000). The strategic spelling skills of students with learning disabilities: the results of two studies. Journal of Instructional Psychology, 27(1), 15-26.

Deacon, S. H., \& Bryant, P. (2005). What young children do and do not know about the spelling of inflections and derivations. Developmental Science, $8(6), 583-594$

Devonshire, V., \& Fluck, M. (2010). Spelling development: fine-tuning strategy-use and capitalizing on the connections between words. Learning and 
Instruction, 20(5), 361-371

Fletcher, J. M., Denton, C., \& Francis, D. J. (2005). Validity of alternative approaches for the identification of learning disabilities: operationalizing unexpected underachievement. Journal of Learning Disabilities, 38(6), 545552.

Frith, U. (1985). Beneath the surface of developmental dyslexia. In K. E. Patterson, J. C. Marshall, \& M. Coltheart (Eds.), Surface dyslexia (pp. 301-330). London: Taylor and Francis.

Furnes, B., \& Samuelsson, S. (2010). Predicting reading and spelling difficulties in transparent and opaque orthographies: a comparison between Scandinavian and US/Australian children. Dyslexia, 16(2), 119-142.

Goswami, U. (1992). Annotation: phonological factors in spelling development. Journal of Child Psychology and Psychiatry and Allied Disciplines, 33(6), 967-975.

Green, L., McCutchen, D., Schwiebert, C., Quinlan, T., Eva-Wood, \& A, Juelis J. (2003). Morphological development in children's writing. Journal of Educational Psychology, 95(4), 752-761.

Han, A. N., Kim, I. S., Kim, T. H., \& Yu, M. N. (2014). Current status of use and educational availability through analysis of gamification cases. Proceeding of the 2014 conference of the Korean Studies Information Service System, 363-373.

Hwang, B. M., Kwon, S. B., Kim, S. J., \& Shin, B. J. (2017). A basic study of verbs list for vocabulary learning based on augmented reality. Journal of Rehabilitation Research, 21(2), 233-246.

Hebert, M., Kearns, D. M., Hayes, J. B., Bazis, P., \& Cooper, S. (2018). Why children with dyslexia struggle with writing and how to help them. Language, Speech, and Hearing Services in Schools, 49(4), 843-863.

Henderson, E. H. (1985). Teaching spelling. Boston: Houghton Mifflin.

Henderson, E. H. (1990). Teaching spelling (2nd ed.). Boston, MA: Houghton Mifflin.

Henry, M. K. (1989). Children's word structure knowledge: Implications for spelling and decoding instruction. Reading and Writing: An Interdisciplinary Journal, 1(2), 135-152.

Holmes, V. M., \& Castles, A. E. (2001). Unexpectedly poor spelling in university students. Scientific Studies of Reading, 5(4), 319-350.

Holmes, V. M., \& Ng, E. (1993). Word-specific knowledge, word-recognition strategies, and spelling ability. Journal of Memory and Language, 32(2), 230257.

Jang, H. J., Jeon, H. S., Shin, M. S., \& Kim, H. J. (2014). Study on selection of basic vocabulary for elementary school students: focused on basic vocabu- lary in the lower grades. Journal of Speech-Language \& Hearing Disorders, 23(2), 157-170.

Jang, Y. Y. (2018). The effects of intervention using gamification-based reading instruction application on word recognition ability of children with reading difficulties (master's thesis). Ewha Womans University, Seoul, Korea.

Joshi, R. M., \& Aaron, P. G. (2002). Naming speed and word familiarity as confounding factors in decoding. Journal of Research in Reading, 25(2), 160-171.

Jung, S. I. (2005). Invented spelling: spelling error analysis in Korean kindergarten children (master's thesis). Ewha Womans University, Seoul, Korea.

Jung, K. H. (2019). Developmental characteristics of spelling ability of kindergarten to 3rd grad children. Communication Sciences \& Disorders, 24(1), 19-30.

Kamhi, A. G., \& Hinton, L. N. (2000). Explaining individual differences in spelling ability. Topics in Language Disorders, 20(3), 37-49.

Kamhi, A. G., \& Catts, H. W. (2012). Language and reading disabilities (3rd ed.). Boston, MA: Allyn and Bacon.

Khowaja, K., \& Salim, S. S. (2019). Serious game for children with autism to learn vocabulary: an experimental evaluation. International Journal of Human-Computer Interaction, 35(1), 1-26.

Kim, E. H. (2009). Spelling skills of elementary students in Korea: focusing on spelling accuracy and error patterns. The Journal of Elementary Education, 22(4), 85-113.

Kim, E. H., \& Kim, Y. J. (2015). The effects of spelling instruction based on Korean language characteristics on spelling achievement of words with final double in students with writing disabilities. The Korea Journal of Learning Disabilities, 12(3), 43-67.

Kim, Y. T., Jae, H. S., Jung, G. H., Kim, Y. R., Pae, S., Choi, E. J., Jung, S. I., \& Kim, H. C. (2020). Validity and sensitivity · specificity of quick assessment of childhood reading \& writing. Communication Science \& Disorders, 25(1), 1-13.

Kim, J. Y., Kang, M. K., \& Kim, Y. T. (2019). The impact of phonological awareness and phonological working mmory training on the reading disabilities of children during their early years of elementary school. Special Education Research, 18(2), 5-28.

Kim, W. S., Lee, S., Seo, J. H., Jeong, D. E., Cheon, J. M., \& Choi, K. Y. (2015). An analysis of vocabulary in Korean elementary school textbooks. Journal of Speech-Language \& Hearing Disorders, 24(4), 33-44.

Kirk, C., \& Gillon, G. T. (2009). Integrated morphological awareness intervention as a tool for improving literacy. Language, Speech, and Hearing 
Services in Schools, 40(3), 341-351.

Lee, J. K., Shin, G. Y., Yoon, H. J., \& Pae, S. Y. (2015). Morpheme and orthographic knowledge-based writing intervention for children with poor orthographic knowledge. Journal of Leaner-Centered Curriculum and Instruction, 15(6), 139-156.

Lee, J. S., \& Cho, H. J. (2010). A study on the effects of game-play reading program for children with reading difficulties. The Korean Journal of Developmental Psychology, 7(2), 77-99.

Lee, K. K. (2008). School grammar theory. Seoul: Worin.

Lee, K., \& Chung, M. (2002). Statistical analysis of Korean phonological variations using grapheme-to-phoneme system. The Journal of the Acoustical Society of Korea, 21(7), 656-664

Lee, M. R., Choi, E. J., \& Kim, Y. T. (2020). Sensitivity and specificity of writing assessment using spelling scoring metrics. Journal of Speech-Language \& Hearing Disorders, 29(20), 47-55.

Lee, P. Y., \& Kim, J. S. (2008). A study on the vocabulary frequency and distribution in spoken language of elementary school students. Korean Language Education Research, 33, 557-595.

Lee, S., Park, E., \& Kim, Y. T. (2000). Single subject research in educational and clinical settings. Seoul: Hakjisa.

Lee, S. J. (2018). A study about diagnosis and intervention of basic writing underachievements. Journal of CheongRam Korean Language Education, 65, 153-183.

Lee, S. O. (1990). On the functional load of phonetic/phonological rules: a quantitative survey in modern Korean. Language Research, 26(3), 441-467.

Mattison, R., E., Hooper, R. S., \& Glassberg, L. A. (2002). Three-year course of learning disorders in special education students classified as behavioral disorder. Journal of the American Academy of Child and Adolescent Psychiatry, 41(12), 1454-1461.

Maria, D. V. Z., \& Jhonny, S. V. (2020). Recreational games to strengthen equilibrium and oral expression of children with down syndrome. Theory a Practice in Language Studies, 10(4), 360-371.

McCutchen, D., Stull, S., Herrera, B. L., Lotas, S., \& Evans, S. (2014). Putting words to work: effects of morphological instruction on children's writing. Journal of Learning Disability, 47(1), 86-97.

Myhill, D. (2008). Towards a linguistic model of sentence development in writing. Language and Education, 22(5), 271-288.

Nagy, W., Berninger, V. W., \& Abbott, R. D. (2006). Contributions of morphology beyond phonology to literacy outcomes of upper elementary and middle-school students. Journal of Educational Psychology, 98(1), 134-147.
Noor, M., Shahbodin, F., \& Pee, C. (2012). Serious game for autism children: review of literature. Proceedings of World Academy of Science, Engineering and Technology, 554-559.

Nunes, T., \& Bryant, P. (2006). Improving literacy by teaching morphemes. New York: Routlege.

Nunes, T., Bryant, P., \& Losson, J. (2003). Learning morphological and phonological spelling rules: an intervention study. Scientific Studies of Reading, 7(3), 9-307.

O’Connor, R. E., Beach, K. D., Sanchez, V. M., Bocian, K. M., \& Flynn, L. J. (2015). Building BRIDGES: a design experiment to improve reading and United States history knowledge of poor readers in eighth grade. Exceptional Children, 81(4), 399-425.

Pae, S. Y, Kim, M. B., Yoon, H. J., \& Jang, S. M. (2015). Korean Language-Based Reading Assessment. Seoul: Hakjisa.

Park, H. (2014). Korean version of Comprehensive Test of Nonverbal Intelligence second edition (K-CTONI-2). Seoul: Mindpress.

Park, H. O., \& Chung, Y. S. (2008). A study on dictation errors and dictation error characteristics of the elementary student. The Journal of Special Education: Theory and Practice, 9(4), 367-395.

Park, J. H. (2017). The elements of Gamification in John Dewey's pedagogy. Journal of Korea Game Society, 17(2), 7-15.

Parker, R. I., Vannest, K. J., \& Brown, L. (2009). The improvement rate difference for single-case research. Exceptional Children, 75(2), 135-150.

Pennington, B. F., McCabe, L. L., Smith, S. D., Lefly, D. L., Bookman, M. O., Kimberling, W. J., \& Lubs, H. A. (1986). Spelling errors in adults with a form of familial dyslexia. Child Development, 57(4), 1001-1013.

Rubin, H. (1988). Morphological knowledge and early writing ability. Language and Speech, 31(4), 337-355.

Sangster, L., \& Deacon, S. H. (2011). Development in children's sensitivity to the role of derivations in spelling. Canadian Journal of Experimental Psychology, 65(2), 133-142.

Shin, G. Y., Seol, A. Y., Cho, H. S., Nam, K. C., \& Pae, S. Y. (2015). Korean spelling development and linguistic patterns. Journal of Speech-Language \& Hearing Disorder, 21(2), 61-72.

Shin, S. W., \& Cho, S. C. (2001). Comparative study upon the characteristics of writing between the patients with writing disabilities and normal elementary school students. Koran J child and Adol Psychiatr, 12(1), 51-70.

Shippen, M. E., Reilly, A., \& Dunn, C. (2008). The effect of the intensity of spelling instruction for elementary students at risk for school failure. Journal of Direct Instruction, 8(1), 19-28. 
Sung, I. J. (1988). A study on the development of a program for improving thinking power (II). Jincheon: Korea education development institute.

Treiman, R., Cassar, M., \& Zukowski, A. (1994). What types of linguistic information do children use in spelling? The case of flaps. Child Development, 65(5), 1318-1337.

Vadasy, P., Sanders, V., \& Peyton, J. (2006). Para educator supplemented instruction in structural analysis with text reading practice for second and third graders at risk for reading problems. Remedial and Special Education, $27(6), 365-378$.

Vaughn, S., Cirino, P. T., Wanzek, J., Wexler, J., Fletcher, J. M., Denton, C. D., \& Francis, D. J. (2010). Response to intervention for middle school students with reading difficulties: effects of a primary and secondary intervention. School Psychology Review, 39(1), 3-21.

Yang, M. (2014). Children's spelling of phonological and morphological features in primary grades. Communication Sciences and Disorders, 19(10), 120-131.

Yang, M. (2006). A review of theory and research about cross-linguistic spell- ing development. Korean Journal of Special Education, 41(3), 163-186.

Yang, M. (2009). Spelling development of kindergarten students: a one year longitudinal study. Korean Journal of Communication \& Disorders, 14(1), 14-33.

Yang, M., \& Lee, A. J. (2016). Influences of linguistic awareness on primary grade children's spelling abilities. The Korea Journal of Disabilities, 13(3), $67-90$.

Yi, S. H., \& Lee, T. S. (2013). The effects of a game-based language application on word recognition and attention span ability of students with intellectual disabilities. The Journal of Special Children Education, 15(4), 265283.

Zakari, H., Ma, M., \& Simmons, D. (2014). A review of serious games for children with Autism Spectrum Disorders (ASD). Proceeding of the Serious Games Development and Applications, 93-106.

Weiner, S. (1994). Effects of phonemic awareness training on low-and middle-achieving first graders' phonemic awareness and reading ability. Journal of Reading Behavior, 26(3), 277-300. 
Appendix 1. Assessment wordlist

\begin{tabular}{rccc}
\hline 번호 & 음운규칙 & 훈련 어절 & 비훈련 어절 \\
\hline 1 & 연음화 & 앞은[아픈] & 답은[다븐] \\
2 & & 속이[소기] & 높아[노파] \\
3 & & 곳에[고세] & 닫은[다든] \\
4 & & 있어[이써] & \\
5 & & 같아[가타] & \\
6 & & 찾은[차즌] & \\
7 & 경음화 & 집도[집또] & 책도[책또] \\
8 & & 걷고[걷꼬] & 잡다[잡따] \\
9 & & 작고[작꼬] & 쉽게[쉽께] \\
10 & & 춥다[춥따] & \\
11 & & 먹다먹따] & \\
12 & & 받게받께] & \\
13 & & 것만[건만] & 듣는[든는] \\
14 & 비음화 & 적는[정는] & \\
15 & & 쌓다[싸타] & \\
16 & 격음화 & 좋고[조코] & \\
17 & & 넣은[너은] & 닿아[다아] \\
18 & 할락 & 끝이[끄치] & 밑이[미치] \\
\hline
\end{tabular}

Appendix 2. Operational definitions of error type

\begin{tabular}{|c|c|c|}
\hline 오류 유형 & 조작적 정의 & 예시 \\
\hline \multicolumn{3}{|l|}{ 글자소 오류 } \\
\hline 생략 & 목표 어절 중 글자소를 생략한 경우 & 앞은 $\rightarrow$ 아은 \\
\hline 대치 & 목표 어절 중 글자소를 대치한 경우 & 좋고 $\rightarrow$ 촣고 \\
\hline 첨가 & 목표 어절 중 글자소를 첨가한 경우 & 넣은 $\rightarrow$ 넣흔 \\
\hline \multicolumn{3}{|l|}{ 형태소 오류 } \\
\hline 어휘형태소 & 발음에 영향을 받아 어간과 체언이 변형되는 형태로 어절을 표기하는 경우 & 적는 $\rightarrow$ 정는 \\
\hline 문법형태소 & $\begin{array}{l}\text { 어간과 어미, 체언과 조사의 경계를 구분하지 못하여, 발음에 영향을 받아 어미가 변형되는 형태로 } \\
\text { 어절을 표기하는 경우 }\end{array}$ & 있어 $\rightarrow$ 이써 \\
\hline \multicolumn{3}{|c|}{ 음운규칙 반영 오류 } \\
\hline 연음화 & 목표 어절의 전체를 소리대로 표기하는 경우 & 곳에 $\rightarrow$ 고세 \\
\hline 경음화 & & 작고 $\rightarrow$ 작꼬 \\
\hline 격음화 & & 좋고 $\rightarrow$ 조코 \\
\hline 흐탈락 & & 넣은 $\rightarrow$ 너은 \\
\hline 비음화 & & 적는 $\rightarrow$ 정는 \\
\hline 구개음화 & & 끝이 $\rightarrow$ 끄치 \\
\hline
\end{tabular}




\section{국문초록}

\section{게이미피케이션 기반의 형태론적 쓰기중재가 쓰기부진 아동의 자소-음소 불일치 어절 쓰기에 미치는 영향} 김효희 ${ }^{1} \cdot$ 이영미 ${ }^{1} \cdot$ 홍기형 $^{2} \cdot$ 김영태 ${ }^{1}$

${ }^{1}$ 이화여자대학교 대학원 언어병리학과, ${ }^{2}$ 성신여자대학교 서비스· 디자인공학과

배경 및 목적: 게이미피케이션 기반의 형태론적 쓰기중재가 쓰기부진 아동의 자소-음소 불일치 어절쓰기 능력에 미치는 영향을 살펴 보고자 한다. 방법: 게이미피케이션 기반의 형태론적 쓰기훈련 앱을 활용하여 음운변동 규칙별로 형태지식 훈련을 실시한다. 결과: 중 재 효과, 일반화, 유지에서 모두 효과를 나타냈다. 논의 및 결론: 첫째, 형태지식을 활용한 쓰기훈련은 쓰기부진 아동의 제한된 쓰기 능 력을 촉진할 수 있는 방법으로, 쓰기 발달의 초기 수준이더라도 음운지식에만 국한되지 않고 형태 및 표기지식에 대한 촉진이 함께 이 루어질 필요가 있음을 시사한다. 둘째, 게이미피케이션 기반의 쓰기훈련은 쓰기부진 아동의 흥미와 동기를 이끌어내어 반복적으로 쓰 기훈련을 할수 있고, 대상자의 특성 및 필요에 따라 적합한 중재 도구로 활용할 수 있다.

핵심어: 쓰기중재, 게이미피케이션 기반의 쓰기중재, 쓰기부진 아동, 형태지식, 음운변동규칙

본 연구는 2018 대한민국 교육부와 한국연구재단의 지원을 받아 수행된 연구임(No. NRF-2018S1A3A2075274).

\section{참고문헌}

김영태, 제현순, 정경희, 김영란, 배소영, 최은정, 정상임, 김효창 (2020). 아동 간편 읽기 및 쓰기 발달 검사(QRW) 개발을 위한 타당도 및 민감도와 특 이도 연구. Communication Sciences \& Disorders, 25(1), 1-13.

김애화, 김의정 (2015). 한글의 특성을 반영한 철자 교수가 쓰기장애학생의 겹받침 단어 철자 성취도에 미치는 효과. 학습장애연구, $12(3), 43-67$. 김애화 (2009). 초등학교 학생의 철자 특성 연구: 철자 발달 패턴 및 오류 유형 분석. 초등교육연구, 22(4), 89-113.

김지윤, 강민경, 김영태 (2019). 음운인식 및 음운작업기억 훈련이 초등학교 저학년 읽기부진 아동의 읽기능력에 미치는 효과. 특수교육, 18(2), 5-28. 김화수, 이숙, 서지희, 정다은, 천정민, 최경윤 (2015). 초등학교 1-3학년 국어 교과서 어휘 분석. 언어치료연구, 24(4), 33-44.

박주희 (2017). 존 듀이의 교육학에 나타난 게이미피케이션의 요소들. 한국게임학회, 17(2), 7-15.

박혜옥, 정용석 (2008). 초등학생의 받아쓰기 발달과 오류 특징에 관한 연구. 특수교육 저널: 이론과 실천, 9(4), 367-395.

박혜원 (2014). 한국비언어지능검사-2 (K-CTONI-2). 서울: 마인드프레스.

배소영, 김미배, 윤효진, 장승민 (2015). 한국어 읽기검사(KOLRA). 서울: 학지사.

신가영, 설아영, 조혜숙, 남기춘, 배소영 (2015). 초등학생의 철자 발달과 오류 패턴 분석. 언어치료연구, 24(2), 61-72.

신성웅, 조수철 (2001). 쓰기장애 환자와 정상 초등학교 학생의 쓰기 특성 비교. 소아청소년정신의학, 12(1), 51-70.

성일제 (1988). 사고력 신장을 위한 프로그램 개발 연구(II). 진천: 한국교육개발원.

양민화 (2006). 문자발달과정을 설명하는 범언어적인 이론과 문자간 철자발달의 비교연구 Review. 특수교육학연구, 41(3), 163-186.

양민화 (2009). 유치원 아동의 철자발달 단기종단연구. 언어청각장애연구, 14(1), 14-33.

양민화 (2014). 음운론적 유형과 형태론적 유형의 초기 철자 발달. Communication Sciences \& Disorders, 19(1), 120-131.

양민화, 이애진 (2016). 학령기 초기 아동의 철자 기술에 미치는 언어학적 인식 능력의 영향력 변화. 학습장애연구, 13(3), 67-90.

이경님, 정민화 (2002). 발음별 자동 생성기를 이용한 한국어 음운 변화 현상의 통계적 분석. 한국음향학회지, 21(7), 656-664.

이관 (2008). 학교문법론. 서울: 월인.

이미래, 최은정, 김영태 (2020). 쓰기 채점 방식에 따른 쓰기 검사의 민감도 및 특이도 연구. 언어치료연구, 29(2), 47-55.

이상억 (1990). 현대국어 음변화 규칙의 기능부담량. 어학연구, 26(3), 441-467.

이소현, 박은혜, 김영태 (2000). 교육 및 임상현장 적용을 위한 단일대상연구. 서울: 학지사. 
이수진 (2018). 기초적 쓰기 부진 진단과 중재 방안. 청람어문교육, 65, 153-183.

이승훈, 이태수 (2013). 게임기반 언어훈련 애플리케이션이 지적장애 학생의 단어재인과주의지속 능력에 미치는 효과. 특수아동교육연구, 15(4), 265-

283.

이재국, 신가영, 윤효진, 배소영 (2015). 쓰기부진 초등생의 형태소 및 철자지식을 활용한 문장쓰기 중재 효과. 학습자중심교과교육연구, 15(6), 139-

156.

이종숙, 조희정 (2010). 읽기부진아동을 위한 읽기게임 프로그램 효과. 한국심리학회지: 학교, 7(2), 171-199.

이필영, 김정선 (2008). 초등학생의 구어에 나타난 어휘 빈도와 분포도 조사. 국어교육학연구, 33, 557-595.

장예영 (2018). 게이미피케이션(Gamification) 기반의 읽기 훈련 애플리케이션을 활용한 중재가 저학년 읽기부진 아동의 단어재인 능력에 미치는 효

과. 이화여자대학교 언어병리학과석사학위논문.

장현진, 전희숙, 신명선, 김효정 (2014). 초등학생 교육용 기초 어휘 선정 연구. 언어치료연구, 23(1), 157-170.

정경희 (2019). 유치원에서 초등 3학년 아동의 철자쓰기 발달 특성. Communication Sciences \& Disorder, 24(1), 19-30.

정상임 (2005). 5-6세 아동의 창안적 글자쓰기 발달 단계에 따른 오류 유형 분석. 이화여자대학교 대학원 석사학위논문.

한안나, 김인수, 김태현, 유미나 (2014). 게임화(Gamification) 사례분석을 통한 활용 현황 및 교육적 활용 가능성. 한국교육공학회 춘계학술대회, 363-374.

황보명, 권순복, 김선종, 신범주 (2017). 증강현실 기반 어휘 지도에서 동사 목록에 대한 기초 연구. 재활복지, 21(2), 233-246.

\section{ORCID}

김효희(제1저자, 대학원생 https://orcid.org/0000-0002-6732-4259); 이영미(공동저자, 교수 https://orcid.org/0000-0003-1809-5944);

홍기형(공동저자, 교수 https://orcid.org/0000-0001-7034-4122); 김영태(교신저자, 교수 https://orcid.org/0000-0003-1738-6862) 